\title{
PENGARUH CACING TANAH DAN JENIS MEDIA TERHADAP KUALITAS PUPUK ORGANIK
}

\author{
Ni Luh Kartini \\ Program Studi Agroekoteknologi, Fakultas Pertanian,Universitas Udayana \\ Email: kartini@unud.ac.id
}

\begin{abstract}
ABSTRAK
Cacing tanah adalah salah satu dari makroorganisme tanah yang mempunyai peranan sangat penting menjaga kualitas tanah secara berkelanjutan. Lumbricus rubellus adalah salah satu dari 1800 jenis cacing tanah yang hidup dipermukaan tanah di bawah serasah yang mempunyai kemampuan mendegradasi bahan organik sangat tinggi. Kualitas pupuk kascing sangat dipengaruhi oleh jenis media karena kecepatan melapuk ditentukan oleh $\mathrm{C} / \mathrm{N}$ ratio. Penelitian ini bertujuan untuk mengetahui jenis media yang paling bagus digunakan untuk meningkatkan kualitas pupuk kascing. Penelitian menggunakan Rancangan Acak Kelompok pola factorial dengan dua factor. Faktor pertama adalah populasi cacing terdiri atas 4 taraf (Kontrol, 20 Ekor, 40 Ekor, dan 60 Ekor). Faktor kedua adalah media cacing terdiri atas 4 taraf (slurry sapi $+25 \%$ jerami, slurry babi $+25 \%$ jerami, slurry sapi $+25 \%$ jerami $+25 \%$ sayuran, slurry babi $+25 \%$ jerami $+25 \%$ sayuran) dengan tiga (3) ulangan sehingga terdapat 48 unit percobaan. Hasil penelitian menunjukkan interaksi perlakuan berpengaruh sangat nyata terhadap: Kecepatan melapuk, C-organik, populasi cacing tanah, telur cacing tanah, total populasi mikroorganisme, dan $\mathrm{pH}$ kascing, kecuali P-tersedia dan N-total. Dapat disimpulkan bahwa kualitas kascing terbaik dalam penelitian adalah media slurry sapi $+25 \%$ jerami padi + sampah sayur-mayur dan 60 ekor cacing tanah.
\end{abstract}

Kata kunci : slurry sapi, jerami padi, sampah sayur-mayur, cacing tanah,kascing

\begin{abstract}
Earthworms are one of the soil macroorganisms that have a very important role in maintaining soil quality in a sustainable manner. Lumbricus rubellus is one of 1800 types of earthworms that live on the surface of the soil which has the ability to degrade very high organic matter. The quality of vermicompost fertilizer is strongly influenced by the types of media because decaying speed is determined by the $\mathrm{C} / \mathrm{N}$ ratio. This study aims to determine the type of media that is best used to improve the quality of vermicompost fertilizer. Experiment was used completely randomized blok design in factorial pattern. he first factor is the population of worms consisting of 4 levels (Control, 20 Tails, 40 Tails, and 60 Tails). The second factor is media worms consisting of 4 levels (slurry cattle $+25 \%$ straw, slurry pigs $+25 \%$ straw, slurry cattle $+25 \%$ straw $+25 \%$ vegetables waste, slurry pigs $+25 \%$ straw $+25 \%$ vegetables waste) with three replication so that there are 48 test units. The results showed that the interaction of treatments had a very significant effect on: decay speed, C-organic, population of earthworms, earthworm eggs, total microorganism population, and pH of vermicompost, except $\mathrm{P}$-available and $\mathrm{N}$-total. It can be concluded that the best vermicompost quality in the study was slurry cow $+25 \%$ rice straw + vegetable waste and 60 earthworms.
\end{abstract}

Keywords: cow slurry, rice straw, vegetable waste, earthworm, vermicompost

\section{PENDAHULUAN}

Cacing tanah (Lumbricus rubellus) sering disebut perut bumi karena semua mikroorganisme menguntungkan ada di perut cacing tanah. Cacing tanah yang kelihatan sangat lemah tapi mempunyai kekuatan yang melebihi semua kekuatan yang ada di bumi ini, yaitu kekuatan untuk merubah semua bentuk bahan organik dalam sekejap menjadi tanah subur dan kekuatan lainnya. Cacing tanah termasuk binatang lunak di alam ada 1800 species, tetapi baru sebagian kecil dapat dimanfaatkan. Cacing tanah termasuk binatang yang sangat kompleks karena masing-masing jenis cacing tanah memiliki habitat yang spesifik. Hal ini menyebabkan setiap jenis cacing tanah akan bertahan pada habitatnya masing-masing. Cacing tanah dapat hidup dengan baik pada pH 6 s/d 7,2, kelembaban 12,5 s/d 17,5 dan suhu $15 \mathrm{~s} / \mathrm{d} 31^{\circ} \mathrm{C}$ Cacing tanah adalah salah satu dari makroorganisme tanah yang mempunyai 
peranan sangat penting menjaga kualitas tanah secara berkelanjutan. Lumbricus rubellus salah satu dari 1800 jenis cacing tanah yang hidup dipermukaan tanah di bawah serasah mempunyai kemampuan mendegradasi bahan organik sangat tinggi yaitu dapat memakan bahan organik sebanyak berat badannya sendiri setiap 24 jam .Kascing (pupuk organik bekas cacing) adalah kotoran hasil fermentasi cacing tanah yang mengandung unsur hara yang dibutuhkan oleh tanaman dan dapat langsung dipergunakan .Unsur hara yang terkandung di dalam kascing tergolong lengkap baik hara makro maupun mikro dan tersedia dalam bentuk yang mudah diserap oleh tanaman (Atiyeh $d k k .$, 2000). Cacing memakan bahan organik mati sisa tanaman. Bahan organik yang dimakan kemudian dikeluarkan sebagai kotoran hasil ekskresi, terjadi proses fermentasi dan dekomposisi bahan organik di dalam perut cacing, yang berupa agregat-agregat berbentuk granular dan banyak mengandung unsur hara yang siap tersedia bagi tanaman. Penambahan bahan organik ke dalam tanah akan meningkatkan kemampuan menahan air sehingga kemampuan menyediakan air tanah untuk pertumbuhan tanaman meningkat. Kondisi air yang tersedia akan lebih mudah diserap tanaman dan secara otomatis kadar air pada tanaman tersebut akan mengalami peningkatan sehingga berat segar pada tanaman menjadi bertambah.

Di antara jenis pupuk kandang, pupuk kandang sapi yang mempunyai kadar serat yang tinggi seperti selulosa, hal ini terbukti dari hasil pengukuran parameter $\mathrm{C} / \mathrm{N}$ rasio yang cukup tinggi $>40$. Tingginya kadar $\mathrm{C}$ dalam pupuk kandang sapi menghambat penggunaan langsung ke lahan pertanian karena akan menekan pertumbuhan tanaman utama. Penekanan pertumbuhan terjadi karena mikroba dekomposer akan menggunakan $\mathrm{N}$ yang tersedia untuk mendekomposisi bahan organik tersebut sehingga tanaman utama akan kekurangan N. Untuk memaksimalkan penggunaan pukan sapi harus dilakukan pengomposan agar menjadi kompos pukan sapi dengan rasio $\mathrm{C} / \mathrm{N}$ di bawah 20. Selain masalah rasio $\mathrm{C} / \mathrm{N}$, pemanfaatan pukan sapi secara langsung juga berkaitan dengan kadar air yang tinggi. Petani umumnya menyebutnya sebagai pupuk dingin. Bila pukan dengan kadar air yang tinggi diaplikasikan secara langsung akan memerlukan tenaga yang lebih banyak serta proses pelepasan amoniak masih berlangsung.

Pemanfaatan pukan babi di Indonesia hanya terdapat di beberapa lokasi tertentu yang berdekatan dengan peternakan babi. Pupuk kandang (pukan) babi mempunyai tekstur yang lembek dan akan bertambah cair bila bercampur dengan urine. Peternak babi telah mengetahui bagaimana cara memisahkan urine ini dengan padatannya, lalu menumpukkannya di suatu tempat untuk didekomposisikan terlebih dahulu. Komposisi hara kotoran babi sangat dipengaruhi oleh umur. Di negara-negara seperti Cina, Thailand, dan berbagai negara di Eropa telah dibedakan jenis pukan babi sesuai umur. Akan tetapi, secara umum pukan babi cukup mengandung hara $\mathrm{P}$ tetapi rendah $\mathrm{Mg}$.

Berdasarkan atas latar belakang di atas maka penelitian ini dilaksanakan dengan tujuan untuk menganalisis interaksi antara cacing tanah dengan jenis media dalam meningkatkan kualitas pupuk organik

\section{METODE PENELITIAN}

Percobaan menggunakan rancangan acak kelompok (RAK) pola faktorial. Faktor pertama adalah media cacing tanah (B) dan faktor kedua adalah populasi cacing tanah (C) sebagai berikut :
1. Media Cacing
B1 : Slurry babi $+25 \%$ jerami padi
B2 : Slurry sapi $+25 \%$ jerami padi
B3 : Slurry babi $+25 \%$ jerami padi $+25 \%$ sampah sayuran
B4 : Slurry sapi $+25 \%$ jerami padi +25 Sampah sayuran
2. Populasi Cacing
Po : tanpa penambahan cacing tanah
P1 : 20 Ekor
P2 : 40 Ekor
P3 : 6o Ekor

Dari kedua factor tersebut, diulang sebanyak 3 kali sehingga diperlukan 48 ember percobaan. Parameter yang diamati adalah: (1) Kecepatan melapuk, C-organik, Jumlah cacing tanah, jumlah telur cacing tanah,P-tersedia, Populasi Mikroorganisme (spk g-1 $\left.\mathrm{x} 10^{8}\right), \mathrm{pH}$ dan $\mathrm{N}$-total

Bahan bahan dikumpulkan,masing - masing ditimbang sesuai dengan persentasenya yang berat keseluruhan $2 \mathrm{~kg}$. Jerami dan sampah sayuran dipotong-potong dengan ukuran kurang lebih $2 \mathrm{~cm}$ .dimasukan ke ember keember difermentasi selama 2 minggu ditutup dengan kain diaduk setiap 3 hari dengan menjada kelembannya 50\%. Setelah 2 minggu di media ini siap diletakan cacing tanah.

Cacing tanah dipilih yang besarnya hampir sama dalam kondisi sehat. Bibit cacing diletakan permukaan media biarkan cacing masuk ke dalam media. Pemeliharaannya dengan melakukan pengadukan setiap tiga hari dan menjaga kelemban 50\% . Panen dilakukan pada saat media berwarna coklak kehitamhitaman

Data hasil percobaan dianalisis dengan sidik ragam (anova) dan bila nilai rata-rata perlakuan yang diperoleh menunjukkan pengaruh nyata atau 
sangat nyata, maka dilanjutkan dengan uji BNT (Beda Nyata Terkecil) pada taraf $5 \%$. Untuk melihat keeratan hubungan antar parameter pengamatan dilakukan analisis korelasi (Gomez, 1995).

\section{HASIL DAN PEMBAHASAN}

Berdasarkan hasil analisis statistika diperoleh signifikansi pengaruh media cacing (B) dan populasi cacing tanah (C) serta interaksinya (B $\mathrm{x}$ C) terhadap variabel yang diamati. Interaksi antara media cacing (B) dan populasi cacing tanah (C) (B $\mathrm{x} C$ ) berpengaruh sangat nyata terhadap variabel C-organik, Populasi Cacing Tanah, Telur cacing tanah, Populasi mikroorganisme, $\mathrm{pH}$ media cacing, serta berpengaruh nyata terhadap Kecepatan Melapuk. sedangkan terhadap variabel lainnya berpengaruh tidak nyata. Jenis media cacing (B) berpengaruh sangat nyata terhadap C-Organik, populasi cacing tanah, telur cacing tanah, P-tersedia, pH. Populasi cacing tanah (C) berpengaruh sangat nyata terhadap semua variable penelitian.

Tabel 1. Pengaruh Cacing Tanah dan media cacing tanah terhadap P-tersedia dan $\mathrm{N}$-total pupuk organik kascing

\begin{tabular}{ccc}
\hline Perlakuan & P-tersedia & N-total \\
\hline Slurry & & \\
B1 & $899,50 \mathrm{a}$ & $1,35 \mathrm{a}$ \\
B2 & $841,30 \mathrm{a}$ & $1,34 \mathrm{a}$ \\
B3 & $922,30 \mathrm{a}$ & $1,34 \mathrm{a}$ \\
B4 & $894,01 \mathrm{a}$ & $1,38 \mathrm{a}$ \\
Cacing & & \\
C0 & $794,41 \mathrm{~d}$ & $1,18 \mathrm{~d}$ \\
C1 & $867,37 \mathrm{c}$ & $1,32 \mathrm{c}$ \\
C2 & $919,47 \mathrm{~b}$ & $1,34 \mathrm{a}$ \\
C3 & $975,87 \mathrm{a}$ & $1,38 \mathrm{a}$ \\
\hline
\end{tabular}

Keterangan: Nilai rata-rata yang diikuti oleh huruf yang sama pada faktor dan kolom yang sama menunjukkan perbedaan yang tidak nyata pada uji BNT 5\%.

Hasil analisis P-tersedia pada perlakuan (B3) slurry babi $+25 \%$ jerami padi $+25 \%$ sampah sayuran memiliki kandungan P-Tersedia lebih tinggi yaitu 922,30, sedangkan pada slurry (B2) slurry sapi $+25 \%$ jerami padi memiliki kandungan P-tersedia lebih rendah yaitu 841,30 , namun tidak demikian halnya pada hasil analisis N-total dimana perlakuan slurry (B4) slurry sapi $+25 \%$ jerami padi + 25 sampah sayuran memiliki kandungan $\mathrm{N}$-total lebih tinggi yaitu 1,38 yang berbeda tidak nyata dengan perlakuan yang lain.

Analisi P-tersedia pada perlakuan cacing sebanyak 60 ekor $\left(\mathrm{C}_{3}\right)$ memiliki kandungan P-tersedia lebih tinggi yaitu 975,87 dan untuk perlakuan yang tanpa cacing memiliki kandungan P-tersedia paling rendah yaitu 794,41 yang berbeda nyata dengan perlakuan lainnya. Hal yang sama pada hasil analisis N-Total perlakuan cacing sebanyak 60 ekor $\left(\mathrm{C}_{3}\right)$ memiliki kandungan $\mathrm{N}$-total lebih tinggi yaitu 1,38 dan terendah dengan perlakuan tanpa penggunaan cacing yaitu 1,80 yang berbeda nyata dengan perlakuan lainnya.

Tabel 2. Pengaruh Cacing Tanah dan Media Terhadap Jumlah Cacing Tanah (ekor)

\begin{tabular}{|c|c|c|c|c|}
\hline & B1 & B2 & B3 & B4 \\
\hline \multirow[t]{2}{*}{$\mathrm{CO}$} & $0 \mathrm{a}$ & $0 \mathrm{a}$ & $0 \mathrm{a}$ & $0 \mathrm{a}$ \\
\hline & A & A & A & A \\
\hline \multirow[t]{2}{*}{$\mathrm{C} 1$} & $24.23 b$ & $30.32 b$ & $26,09 \mathrm{~b}$ & $32.15 b$ \\
\hline & A & A & A & A \\
\hline \multirow[t]{2}{*}{$\mathrm{C} 2$} & 39.39 bc & $43.52 b$ & $41.90 \mathrm{~b}$ & $49.30 \mathrm{~b}$ \\
\hline & $\begin{array}{c}A \\
5170 d\end{array}$ & $\begin{array}{c}\text { A } \\
6388 c\end{array}$ & A & A \\
\hline C3 & A & $A B$ & B & B \\
\hline
\end{tabular}

Keterangan: Nilai rata-rata yang diikuti oleh huruf kapital yang sama ke arah baris dan hurup kecil yang sama ke arah kolom menunjukkan pengaruh yang berbeda tidak nyata pada uji BNT $5 \%$.

Jumlah cacing tanah (Tabel 2) dengan perlakuan (B4C3) slurry sapi $+25 \%$ jerami padi +25 Sampah sayuran dengan jumlah cacing tanah 60 ekor memiliki jumlah paling banyak yaitu 75,20, sedangkan dengan perlakuan (B1Co) slurry babi $+25 \%$ jerami padi dengan tanpa cacing tidak ditemui adanya cacing tanah

Menurut Lavelle (1988), aktivitas cacing tanah dalam melakukan dekomposisi bahan organik selain mempengaruhi sifat-sifat fisiknya juga mempengaruhi sifat kimia karena adanya proses mineralisasi dan bahan-bahan organik yang dilakukan oleh mikroorganisme yang dibantu oleh cacing tanah. Peranan cacing tanah dalam proses mineralisasi adalah mempercepat proses tersebut bersama mikroorganisme, sehingga menghasilkan unsur hara yang lebih tersedia bagi tanaman (Albanell et al., 1980 ). Hara yang terakumulasi dalam kascing baik itu hara makro maupun hara mikro merupakan cerminan dari kandungan hara bahan organik sebagai sumber makanan utama cacing tanah.

Pembuatan pupuk kascing sangat dipengaruhi oleh jenis media yang digunakan, karena dengan media yang lebih tapat akan menghasilkan kualitas pupuk kascing yang lebih baik. Beberapa media yang sering digunakan sebagai media pupuk kascing adalah kotoran sapi, kotoran babi dan sluri babi ataupun sluri sapi.

Salah satu hasil proses fermentasi anaerob pada instalasi biogas adalah terbentuknya limbah cair berbentuk slurry . Limbah biogas, yaitu kotoran ternak yang telah hilang gasnya (slurry) merupakan pupuk organik yang sangat kaya akan unsur-unsur yang dibutuhkan oleh tanaman. Bahkan, unsurunsur tertentu seperti protein, selulose, lignin dan lain-lain tidak dapat digantikan oleh pupuk kimia. Slurry mengalami penurunan COD sebesar 90\% dari kondisi bahan awal dan perbandingan BOD/COD slurry sebesar 0,37. Nilai ini lebih kecil dari perbandingan 
BOD/COD limbah cair sebesar 0,5. Slurry juga mengandung lebih sedikit bakteri pathogen sehingga aman untuk digunakan sebagai pupuk (Widodo dkk, 2007 dalam Prariesta dan Winata, 2009). Menurut Suzuki et al (2001) dalam Oman (2003), sludge yang berasal dari biogas (slurry) sangat baik untuk dijadikan pupuk karena mengandung berbagai macam unsur yang dibutuhkan oleh tumbuhan seperti $\mathrm{P}, \mathrm{Mg}$, Ca, K, $\mathrm{Cu}$ dan $\mathrm{Zn}$. Kandungan unsur hara dalam limbah (slurry) hasil pembuatan biogas terbilang lengkap meskipun jumlahnya sedikit. Beberapa penelitian menunjukkan penggunaan pupuk organik cair memberikan dampak positif terhadap pertumbuhan tanaman.

Tabel 3. Pengaruh Cacing Tanah dan Media Terhadap Pelapukan (\%) pada Saat Panen

\begin{tabular}{ccccc}
\hline & B1 & B2 & B3 & B4 \\
\hline C0 & $23.01 \mathrm{a}$ & $28.82 \mathrm{a}$ & $24,05 \mathrm{a}$ & $29.48 \mathrm{a}$ \\
& $\mathrm{A}$ & $\mathrm{A}$ & $\mathrm{A}$ & $\mathrm{A}$ \\
$\mathrm{C} 1$ & $41.29 \mathrm{~b}$ & $49.87 \mathrm{~b}$ & $43.15 \mathrm{~b}$ & $54.24 \mathrm{~b}$ \\
& $\mathrm{~A}$ & $\mathrm{~A}$ & $\mathrm{~A}$ & $\mathrm{~A}$ \\
$\mathrm{C} 2$ & $46.67 \mathrm{~b}$ & $58.29 \mathrm{~b}$ & $48.59 \mathrm{~b}$ & $62.29 \mathrm{~b}$ \\
& $\mathrm{~A}$ & $\mathrm{~B}$ & $\mathrm{~A}$ & $\mathrm{BC}$ \\
$\mathrm{C} 3$ & $58.3012 \mathrm{~b}$ & $70.67 \mathrm{c}$ & $61.29 \mathrm{c}$ & $84.32 \mathrm{c}$ \\
& $\mathrm{A}$ & $\mathrm{B}$ & $\mathrm{A}$ & $\mathrm{C}$ \\
\hline
\end{tabular}

Keterangan: Nilai rata-rata yang diikuti oleh huruf kapital yang sama ke arah baris dan hurup kecil yang sama ke arah kolom menunjukkan pengaruh yang berbeda tidak nyata pada uji BNT 5\%.

Pengaruh cacing tanah dan media (Tabel 3) terhadap pelapukan dengan perlakuan $\left(\mathrm{B}_{4} \mathrm{C}_{3}\right)$ slurry sapi $+25 \%$ jerami padi +25 sampah sayuran dengan jumlah cacing tanah 60 ekor kecepatan melapuk lebih cepat yaitu $84,32 \%$, sedangkan dengan perlakuan (B1Co) Slurry babi $+25 \%$ jerami padi dengan perlakuan tanpa cacing mengalami proses melapuk lebih rendah yaitu $24,23 \%$ yang berbeda nyata dengan perlakuan lainnya.

Tabel 4. Pengaruh Cacing Tanah dan Media Terhadap C-Organik (\%) pada Saat Panen Pupuk Organik

\begin{tabular}{ccccc}
\hline & B1 & B2 & B3 & B4 \\
\hline C0 & $13.53 a$ & $14.68 \mathrm{a}$ & $14.81 \mathrm{~b}$ & $15.08 \mathrm{~b}$ \\
& $\mathrm{~A}$ & $\mathrm{~A}$ & $\mathrm{~A}$ & $\mathrm{~A}$ \\
$\mathrm{C} 1$ & $14.35 \mathrm{a}$ & $15.47 \mathrm{ab}$ & $15.43 \mathrm{ab}$ & $15.56 \mathrm{ab}$ \\
& $\mathrm{A}$ & $\mathrm{A}$ & $\mathrm{A}$ & $\mathrm{A}$ \\
$\mathrm{C} 2$ & $15.28 \mathrm{a}$ & $13.03 \mathrm{ab}$ & $14.78 \mathrm{ab}$ & $14.82 \mathrm{a}$ \\
& $\mathrm{A}$ & $\mathrm{A}$ & $\mathrm{A}$ & $\mathrm{A}$ \\
$\mathrm{C} 3$ & $14.91 \mathrm{a}$ & $14.65 \mathrm{a}$ & $15.65 \mathrm{a}$ & $16.55 \mathrm{~b}$ \\
& $\mathrm{~A}$ & $\mathrm{~A}$ & $\mathrm{~A}$ & $\mathrm{~B}$ \\
\hline
\end{tabular}

Keterangan: Nilai rata-rata yang diikuti oleh huruf kapital yang sama ke arah baris dan hurup kecil yang sama ke arah kolom menunjukkan pengaruh yang berbeda tidak nyata pada uji BNT $5 \%$.

Pengaruh cacing tanah dan media (Tabel 4) terhadap C-organik dengan perlakuan (B1Co) Slurry babi $+25 \%$ jerami padi tanpa cacing kandungan C-organik lebih tinggi yaitu $18,53 \%$, dibandingkan dengan perlakuan (B2C3) Selurry sapi $+25 \%$ jerami padi dengan jumlah cacing 60 ekor memiliki kandungan C-Organik lebih rendah yaitu 11,55\%.

Tabel 5. Pengaruh Cacing Tanah dan Jenis Media Terhadap jumlah Telur Cacing (butir)

\begin{tabular}{ccccc}
\hline & B1 & B2 & B3 & B4 \\
\hline C0 & Oa & Oa & $0 \mathrm{a}$ & $0 \mathrm{a}$ \\
& $\mathrm{A}$ & $\mathrm{A}$ & $\mathrm{A}$ & $\mathrm{A}$ \\
$\mathrm{C} 1$ & $11.93 \mathrm{~b}$ & $12.90 \mathrm{~b}$ & $13.46 \mathrm{~b}$ & $19.70 \mathrm{~b}$ \\
& $\mathrm{~A}$ & $\mathrm{~A}$ & $\mathrm{~A}$ & $\mathrm{~B}$ \\
$\mathrm{C} 2$ & $16.56 \mathrm{~b}$ & $20.97 \mathrm{~b}$ & $25.01 \mathrm{c}$ & $29.77 \mathrm{~b}$ \\
& $\mathrm{~A}$ & $\mathrm{~A}$ & $\mathrm{AB}$ & $\mathrm{B}$ \\
$\mathrm{C} 3$ & $22.13 \mathrm{c}$ & $23.58 \mathrm{bc}$ & $29.97 \mathrm{c}$ & $31.51 \mathrm{bc}$ \\
& $\mathrm{A}$ & $\mathrm{A}$ & $\mathrm{AB}$ & $\mathrm{B}$ \\
\hline
\end{tabular}

Keterangan: Nilai rata-rata yang diikuti oleh huruf kapital yang sama ke arah baris dan hurup kecil yang sama ke arah kolom menunjukkan pengaruh yang berbeda tidak nyata pada uji BNT $5 \%$.

Pengaruh cacing tanah dan media terhadap jumlah telur cacing tanah dengan perlakuan (B4C3) slurry sapi $+25 \%$ jerami padi +25 sampah sayuran dengan jumlah cacing tanah 60 ekor memiliki jumlah telur cacing paling tinggi yaitu 31,51 butir, sedangkan dengan perlakuan yang tanpa menggunakan cacing tanah tidak terdapat jumlah telur cacing tanah (Tabel $5)$.

Tabel 6. Pengaruh Cacing Tanah dan Jenis Media Terhadap Total Populasi Mikroorganisme (spk g-1 x $10^{8}$ )

\begin{tabular}{ccccc}
\hline & B1 & B2 & B3 & B4 \\
\hline C0 & $13.6 \mathrm{a}$ & $12.22 \mathrm{a}$ & $12.02 \mathrm{a}$ & $11.65 \mathrm{a}$ \\
& $\mathrm{A}$ & $\mathrm{A}$ & $\mathrm{A}$ & $\mathrm{A}$ \\
$\mathrm{C} 1$ & $29.58 \mathrm{~b}$ & $42.01 \mathrm{~b}$ & $32.36 \mathrm{~b}$ & $42.80 \mathrm{~b}$ \\
& $\mathrm{~A}$ & $\mathrm{~B}$ & $\mathrm{~A}$ & $\mathrm{~B}$ \\
$\mathrm{C} 2$ & $72.45 \mathrm{c}$ & $89.53 \mathrm{c}$ & $99.34 \mathrm{c}$ & $110.67 \mathrm{c}$ \\
& $\mathrm{A}$ & $\mathrm{A}$ & $\mathrm{A}$ & $\mathrm{B}$ \\
$\mathrm{C}$ & $129.27 \mathrm{~d}$ & $133.62 \mathrm{~d}$ & $121.81 \mathrm{~d}$ & $145.20 \mathrm{~d}$ \\
& $\mathrm{~A}$ & $\mathrm{~A}$ & $\mathrm{~B}$ & $\mathrm{C}$ \\
\hline
\end{tabular}

Keterangan: Nilai rata-rata yang diikuti oleh huruf kapital yang sama ke arah baris dan hurup kecil yang sama ke arah kolom menunjukkan pengaruh yang berbeda tidak nyata pada uji BNT $5 \%$.

Pengaruh cacing tanah dan media terhadap total mikroorganisme tanah dengan perlakuan (B4C3) slurry sapi $+25 \%$ jerami padi +25 sampah sayuran dengan jumlah cacing tanah 60 ekor memiliki total mikroorganisme paling tinggi yaitu 145,20 spk g- ${ }^{1}$ x $10^{8}$, sedangkan dengan perlakuan (B1Co) slurry babi $+25 \%$ jerami padi dengan perlakuan tanpa cacing memiliki total mikroorganisme paling rendah yaitu 13,6 spk g-1 x $10^{8}$ yang berbeda nyata dengan perlakuan lainnya (Tabel 6).

Pengaruh cacing tanah dan media terhadap ph pupuk organik yang dihasilkan dengan perlakuan (B4C3) slurry sapi $+25 \%$ jerami padi +25 sampah sayuran dengan jumlah cacing tanah 60 ekor memiliki pH tertinggi yaitu 8,56, sedangkan dengan perlakuan (B1Co) Slurry babi $+25 \%$ jerami padi dengan 
Tabel 7. Pengaruh Cacing Tanah dan Media Terhadap pH Pupuk organik

\begin{tabular}{ccccc}
\hline & B1 & B2 & B3 & B4 \\
\hline C0 & $6.39 a$ & $6.41 a$ & $6,37 a$ & $6.47 a$ \\
& A & A & A & A \\
C1 & $6.92 a$ & $7.13 a$ & $7.03 a$ & $7.14 a$ \\
& $\mathrm{~A}$ & $\mathrm{~A}$ & $\mathrm{~A}$ & $\mathrm{~A}$ \\
$\mathrm{C} 2$ & $7.14 \mathrm{a}$ & $7.20 \mathrm{a}$ & $7.14 \mathrm{a}$ & $6.96 \mathrm{a}$ \\
& $\mathrm{A}$ & $\mathrm{A}$ & $\mathrm{A}$ & $\mathrm{A}$ \\
$\mathrm{C} 3$ & $7.35 \mathrm{~b}$ & $7.25 \mathrm{~b}$ & $7.38 \mathrm{a}$ & $7.56 \mathrm{~b}$ \\
& $\mathrm{~A}$ & $\mathrm{~B}$ & $\mathrm{~A}$ & $\mathrm{~B}$
\end{tabular}

Keterangan: Nilai rata-rata yang diikuti oleh huruf kapital yang sama ke arah baris dan hurup kecil yang sama ke arah kolom menunjukkan pengaruh yang berbeda tidak nyata pada uji BNT $5 \%$.

perlakuan tanpa cacing memiliki $\mathrm{pH}$ terendah yaitu 6,39 yang berbeda nyata dengan perlakuan lainnya (Tabel 7).

Cacing tanah dan media sangat mempengaruhi kualitas pupuk organik yang dihasilkan. Jumlah cacing tanah semakin tinggi pada jenis media yang berbeda memberikan pengaruh yang berbeda terhadap kualitas kompos. Semua parameter yang diamati samua berpengaruh nyata sampai sangat nyata, terjadi interaksi kecuali pada P-tersedia dan N-total pada pupuk organik bekas cacing (kascing).Berdasarkan hasil penenelitian menunjukkan bahwa jenis media secara tunggal tidak menyebabkan ada perubahan pada P-tersedia kascing demikian juga dengan $\mathrm{N}$-total kascing. Hal ini terjadi karena kandungan masingmasing jenis media sama sama bahan organik yang memiliki kadar $\mathrm{P}$ dan $\mathrm{N}$ yang hampir sama. Perlakuan jumlah cacing secara tunggal dapat meningkatkan P-tersedia dan N-total kascing.Peningkatan P-tersedia terjadi karena dalam tubuh cacing tanah bersimbiosa berbagai macam mikroorganisme yang bisa menghasilkan enzim fosfatase yang berfungsi meningkatkan ketersediaan P seperti Mikrobia pelarut fosfat, bakteri pelarut fosfat yang mampu memecah ikatan fosfat yang tadinya tidak tersedia menjadi tersedia. Peningkatan $\mathrm{N}$-total pada kascing karena adanya Azotobacter dalam tubuh cacing cacing tanah yang dapat mengikat $\mathrm{N}$ yang bebas yang ada di udara.

Cacing tanah dan jenis medianya secara bersama sama dapat meningkatkan pelapukan bahan organik, dimana proses pelapukan pada masing masing jenis media dipengaruhi oleh jumlah oleh jumlah cacing tanah, semakin banyak cacing tanah pada media campuran sllury sapi, jerami padi dan sayuran semakin cepat terjadi pelapukan. Jumlah cacing 60 ekor memberikan kecepatan pelapukan tertinggi. Hal ini terjadi karena media hidup cacing tanah sekaligus sebagai makanan cacing tanah, keanekaragaman sumber bahan organik sebagai media hidup cacing tanah akan menyebabkan akan meningkatkan aktivitas cacing tanah hal ini terbukti pada perlakuan ini jumlah cacingnya paling tinggi . Tingkat pelapukan yang tinggi membuktikan C-organik tertinggi pada perlakuan ini, pada perlakuan ini terdapat jumlah populasi mikroorganisme teringgi demikian juga pHnya tertinggi . dan jumlah telur cacing. Aktivitas cacing tanah meningkat ketika tersedia sumber makanan.

\section{SIMPULAN}

Berdasarkan hasil penelitian pengaruh cacing tanah dan media terhadap kualitas pupuk organik bekas cacing (kascing), dapat disimpulkan bahwa jumlah cacing tanah dan jenis media secara bersama sama (berinteraksi) berpengaruh sangat nyata terhadap pelapukan, C-organik, jumlah cacing tanah, jumlah telur cacing, jumlah populasi mikroorganisme dan $\mathrm{pH}$ kascing. Pelapukan yang paling tinggi pada perlakuan cacing tanah 60 ekor dengan sllury sapi+jerami padi +sayuran. Kualitas pupuk organik bekas cacing (kascing) terbaik pada perlakuan cacing tanah 60 ekor dengan medianya sllury sapi+jerami padi +sayuran .

\section{DAFTAR PUSTAKA}

Atiyeh, R.M., J. Dominguez, S. Subler, and C.A. Edwards. 2000. Changes in biochemical properties of cow manure during processing by wearthworm (Eisenia andrei) and the effects on seedling growth. Pedobiologia 44 :709-7724.

Briljan, H. S. Pemanfaatan Crotalaria retusa (L.) dan "Kascing" Sebagai Pupuk Organik Untuk Sayuran Selada (Lactuca sativa). Agroteknolgi Fakultas Pertanian Unsika. Majalah Ilmiah Solusi Unsika. Vol. 10 No. 20

Lavelle, P.1988. Earthworm Activities and The Soil System. Biol. Fertil. Soil 6 : 237-251.

Albanell, E., Plaixats, J. and T. Carbero. 1988. Chemical Changes During Vermicomposting (Eisenia foetida) of Sheep Manure Mixed with Cotton Industrial Waste. Biol. Fertil. Soil. 6 : 266-269.

Palungkun, R. 1999. Sukses Beternak Cacing Tanah Lumbricus rubellus. Jakarta : Penebar Swadaya.

Yudiarsana I.M., 2009. “Pengaruh Dosis Pupuk Kascing dan Jarak Tanam Terhadap Pertumbuhan dan Hasil Tanaman Nilam (Pogostemon cablin Benth) di Lahan Kering" (tesis). Denpasar : Universitas Udayana.

Karnata, N. 2000. "Pengaruh Waktu Tanam dan Jenis Pupuk Organik Terhadap Pertumbuhan dan Hasil Kentang (Solanum tuberosum L.) di Lahan Kering Beriklim Basah” (tesis). Denpasar: Universitas Udayana.

Sutanto, R. 2007. Dasar-Dasar Ilmu Tanah. Konsep dan Kenyataan. Yogyakarta: Kanisius. 